\title{
Information sharing in the context of business cooperation - as a source of competitive advantage
}

\author{
Renáta Myšková \\ MLAS School of Business, Czech Technical University in Prague, \\ Crech Republic \\ renata.myskova@cout.cr.

\section{Michal Kuběnka} \\ Faculty of Economics and Administration, University of Pardubice, \\ Crech Republic \\ michal.kubenka@upce.cr.
}

Abstract. One of the problems that SMEs are facing in the long run is lack of external information to assess opportunities and threats in their business environment. This is due to specific management system of SMEs, where management levels are merged, as stated in the article, and management often focuses only on addressing current issues and fails to adequately respond to changes in the business environment. One way of acquiring relevant information about the external environment is mutual information sharing in the context of SMEs cooperation or in cooperation with a large company. The conducted empirical research mapped the levels of management in one of the distribution networks in Czech Republic and focused on defining the areas that need information support, determining their significance from the point of view of participating companies, and their willingness to provide information. Outcomes have shown the need for external information for SMEs, but information sharing between SMEs focuses only on some areas - customerrelated information and information about existing competitors is preferred. From the viewpoint of the manufacturing company, it was found that the information provided by distributors helped to supplement data available to management of the company. So far, the issue of information sharing has been largely addressed at the supply chain level, so this empirical research of the entire sector of competing firms is unique and, stemming from Porter's Five Forces analysis and frequency analysis, brings in new information.

Keywords: SMEs cooperation, information sharing, management in SMEs, Czech Republic, empirical research, Porter's Five Forces analysis, frequency distribution, percentage analysis

JEL Classification: L14, L26, D22 


\section{INTRODUCTION}

One of the problems of Czech business environment is the persisting isolation of businesses in terms of sharing information. A company's success is based on its agility and the ability to respond flexibly to changes in the environment, as the company has to adapt quickly to changes in market conditions. Changes in the economy of the third millennium are brought about by the growing importance of information as a strong economic resource. nformation represents a great growth potential for every business; in this sense, one can refer to information as "the wealth of business" that is dependent on communication methods not only within the enterprise but also with its surroundings.

In the context of a rapidly changing environment, it is necessary to not only define corporate strategy properly but also to evaluate and possibly rebuild it more frequently. The problem, especially of small or medium-sized businesses, is the lack of information needed for such strategic management. This information is obtained through analyses, namely of the external environment (assessment of the effects of macroenvironment and microenvironment) and internal resources and capabilities of business.

In practice, small and medium-sized businesses are better able to analyse internal resources and own capabilities, but the shortcomings are reflected in the analysis of the environment, especially the microenvironment of the company. The reason is the lack of necessary information and of the ability to analyse the obtained information with sufficient accuracy.

One solution to alleviate these problems and shortcomings is to link small businesses in terms of both formal and informal agreements on the alignment of management, marketing and services, which requires information sharing.

Transfer of information may be formal in the sense of its precise contractual definition in terms of technical security and the extent and structure of information that will be shared, or informal, usually in the form of discussions.

The missing strategically important information can be obtained by small businesses in cooperation with a large enterprise that has such information at its disposal as a part of its strategic management. This is, of course, possible only in case of close cooperation. This article focuses specifically on the use of the abovementioned options in the context of cooperation of a manufacturing company with the companies in its distribution network. The aim is to assess the interest of individual management in information sharing and to specify the areas that are suitable for information support and sharing.

To this end, literature review is stated in chapter 2, chapter 3 includes methodology. The management system of small and medium-sized enterprises is described and the possibility of sharing information to strengthen the strategic level of management in small enterprises is theoretically defined. Subsequently, research that took place among the businesses cooperating with the manufacturer within the distribution network is described. The findings are presented and discussed (in chapter 4) in order to locate important areas where information helps increase the competitive ability of respondents and expand further cooperation opportunities. The conclusion (in chapter 5) summarizes the findings.

\section{LITERATURE REVIEW}

A large enterprise is significant in terms of its production volume, but given the low frequency of large enterprises, the role of SMEs is globally much more significant, as confirmed by a number of statistics and studies, as reported by Dixit \& Pandey (2011), Ključnikov et al. (2016), Meixner et al. (2017), Cepel et al. (2018), and others. SMEs are the most important category of business entities in the Czech economy. This is confirmed by the statistics from the Ministry of Industry and Trade (MPO) from 2017, according to which the share of SMEs in the total number of active business entities was $99.8 \%$, the share of the value added was $54.6 \%$ and the share of SME employees in the total number of employees of the 
business sphere in the Czech Republic was 58.0\%. The importance of SMEs within the European Union is similar, as stated by a number of experts and statisticians. Kaufmann et al. (2012) give examples of acronyms of SMEs like "heart of an economy" or "Gold Dust for an efficient economy". For example, Poufinas et al. (2018) say that "SMEs are the backbone of most economies and in particular of the economies of the European countries". According to statistics, they represent $99 \%$ of all businesses in the European Union (EU). Small and medium-sized enterprises are generally considered to be one of the largest employers, accounting for two-thirds of the total employment of the private sector in the EU (authors refer to the 28 countries of the European Union).

Belás et al. (2014) state that the SME segment has its own characteristics and disadvantages, which are transformed into business risk. Authors divide business risk into market risk, financial risk, personal risk, operational and other risks. For example, Hudaková et al. (2018) comprise the four most important risks that negatively affect the business environment of SMEs as a market, financial, personnel and economic risks. According to Hudaková et al. (2018), the dependence perceived by the SME entrepreneurs was found among market factors, personnel risks, and business size. Kirschenmann \& Norden (2012) and Neuberger \& Räthke (2009) claim that small firms are characterized by higher information asymmetry and credit risk. According to Brien \&Hamburg (2014), SMEs have a distinct advantage over large companies in that they have less bureaucracy and hierarchical restrictions and can implement changes quickly. However, often they are slow to change their way of doing business and collaborate. Nevertheless, there are a number of shortcomings that are associated with the characteristics of SMEs. One of the major existing problems for SMEs is the lack of resources (financial, human, technological) needed for the implementation of customer requirements (customer purchase) (Škarpová \& Grosová, 2015). Desouza \& Awazu (2006) focused their research on the ability to use information and knowledge, and their research confirms that SMEs do not manage knowledge the same way as larger companies. The limited use of external knowledge is also mentioned by Muscio (2007). Achterberg (2018) emphasizes the need for external information as a key prerequisite for successful pricing strategies for small and medium-sized enterprises (SMEs).

Virglerová et al. (2016) addressed the issues of financial risk management in SME segment in the Czech Republic. The more difficult conditions for obtaining loans in the Czech Republic are stated by Belás et al. (2016). Research in Slovakia (Kljucnikov et al., 2018) discovered existence of the statistically significant relationship between the solvency problems of SMEs and the payment discipline of their customers (model may explain up to $73.66 \%$ of the variability of payments problems). In this context, Hornal et al. (2018) report that many SMEs have failed by overextending themselves across multiple EU markets. Sometimes, they miss opportunities to leverage local funding sources to augment commercialisation.

SMEs seek to eliminate their own shortcomings through various forms of cooperation and pooling of SMEs into larger entities so that members of such an entity/information base have the benefits of SMEs, while at the same time gaining the benefits of large enterprises. The professional public emphasizes the need for SMEs to cooperate and specifies the number of areas that are appropriate for this. For example, a cluster can be a specific form of collaboration and sharing not limited to just information. It provides an opportunity to eliminate certain shortcomings of SMEs in research, development and sharing of information and investment. Clusters already have a certain tradition in the Czech Republic, as exemplified by, for example, Pavelková \& Jirčíková (2008) or Bednářová (2008), who introduced their various benefits not only for SMEs in 2008.

The benefits of collaboration of SMEs are also presented by the study of Škarpová \&Grosová (2015) on Business Network approach within SME based on the customer's buying behaviour. The study 
concluded that using business network approach has resulted in creating strong relationships in business network, thus building a stronger network and gaining a competitive advantage for SMEs.

Galdeano et al. (2016) introduce the term "co-opetition" in the context of the need for a combination of cooperation and competition strategies in the market environment of SMEs especially in the context of marketing internationalisation. They found the positive effect of strategies of cooperation with competitors on international marketing activity in the area of logistics, promotion, quality and R\&D. Levy et al. (2003) emphasize that co-opetition entails sharing the knowledge that may be a key source of competitive advantage. This is why they have designed a game-theoretic framework for analysing interorganisational knowledge sharing under co-opetition. Achterberg (2018) emphasizes the need for external information as a key prerequisite for successful pricing strategies for small and medium-sized enterprises. Zeng et al. (2010) indicate that there are significant positive relationships between inter-firm cooperation and innovation performance of SMEs, of which inter-firm cooperation has the most significant positive impact on the innovation performance of SMEs.

Generally in literature, the issue of sharing information between subjects is largely discussed in the supply chain, e.g. Pooe et al. (2015), Kumar et al. (2016), Ryad et al. (2016) Sohn \& Lim (2008) focused on the high-tech industry in their research and emphasize that significant impact on supply chain performance has a selection of information sharing policy and forecasting method. Pan et al. (2016) confirm this fact and state that the forecasting method and IS policy are the critical factors in order to achieve cost reduction.

Existing research has so far focused primarily on the following:

- identifying and analyse different forms of cooperation and competition e.g. Bengtsson \& Kock (1999) or Bengtsson et al. (2010),

- benefits related to coopetition (e.g. Ritala \& Tidström, 2014),

- dynamics of coopetation e.g. Dahl (2014) or Tidström \& Hagberg-Andersson (2012),

- tensions and conflicts in cooperation and competition e.g. Fernandez, Le Roy, \& Gnyawali (2014), Tidström (2014).

Investigating the frequency of sharing information within a coopetition is unique. So far, studies have not focused specifically on sharing information in a particular industry and finding out the frequency and extent of information transmitted. Such information is presented in this article based on the results of the own survey. The survey was conducted as a qualitative case study as well as most of the investigations mentioned above. That is because case study was considered as the most appropriate research approach for a new research subject and business networks analysis with quantification of phenomena in form of frequency distribution and percentage analysis.

The importance of sharing information can be expressed through the benefits of sharing information. Chadler (2018) gives examples faster product/service development, wider selection of products/services, improved quality of products/services (features, speed etc). Howlett et al. (2012) highlight the benefits of inter-organizational information sharing, such as prerequisites for the consolidation of inter-organizational relations, antecedents for the improvement of product development, see Lawson et al. (2009), antecedents for the innovation capacity and performance of organizations, more Mei \&Nie (2007), Wijk et al. (2008), antecedents for the development of new strategies and customer satisfaction Zhang et al. (2006). 


\section{METHODOLOGY}

Based on the characteristics of SMEs, management levels are defined and the hypotheses formulated, stemming from the need to obtain significant information to improve the competitive ability, especially information about the external business environment. Hypotheses are verified on the basis of empirical research that took place in autumn 2018. Both the population and the research data sample are described in the chapter devoted to the questionnaire survey (chapter 3.3 Empirical research).

\subsection{Management system in SMEs}

In spite of some complexity and instability of the socio-economic reality, it is the main role and priority of management of any business to seek solutions that will improve the overall state of the company. Therefore, it is necessary to accept generally applicable changes in the environment and to respond flexibly in the short, but especially in the long term. The priority of top management is therefore clear: to set such a course towards achieving the goal, in which the advantages of the business are best applied. Small businesses face a vicious circle: how to look for and identify all business assets if the crucial information is missing?

In the case of small businesses, in particular, the management powers are concentrated in the hands of only a few people, and therefore there is no division of management into middle and top management; tactical and strategic management is the responsibility of only a handful of managers, or, in some cases, just the owner of the company. Taking this into account as one of the characteristics of small enterprises, the three-level management scheme (Fig. 1a) changes into an internal pyramid that includes only two levels, as the notional line separating strategic and tactical management in this case does not exist; both strategic and tactical management is the responsibility of the same managers (Fig. 1b). For this reason, there is a change in the information system (hereinafter referred to as IS) of the company, where management can be defined as one-level, namely managerial.

The professionally designed core of the IS (inner pyramid) is surrounded by means of internal and external communication - these areas are becoming increasingly important. The method of communication can be considered one of the criteria for assessing the quality of the company's management systems.
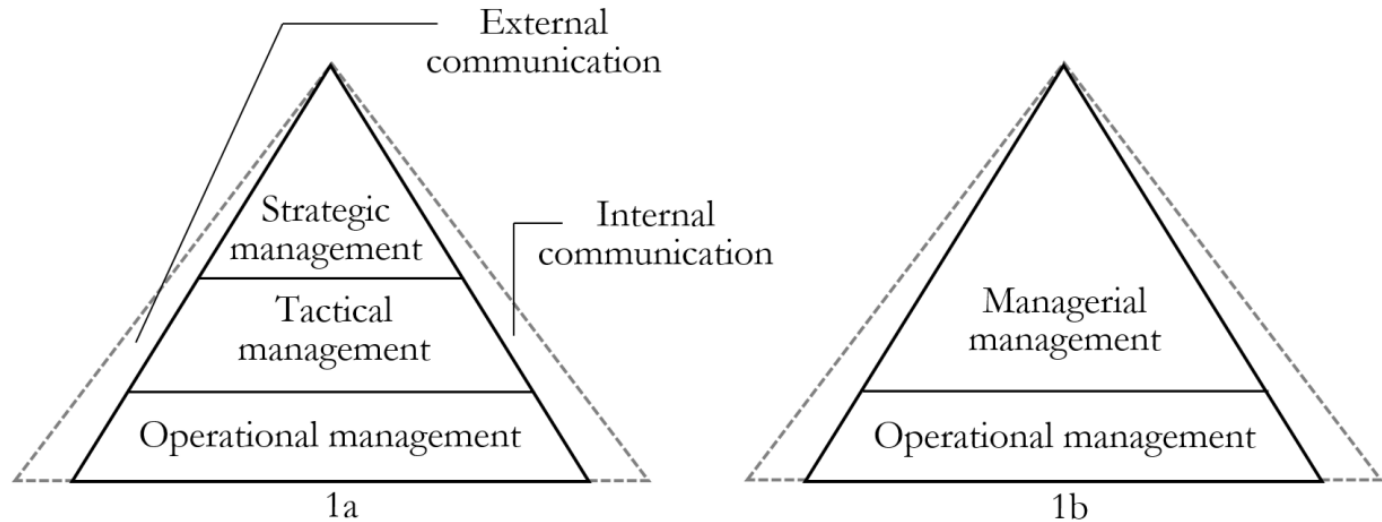

Figure 1. Management levels and information system in a small business Source: (Myšková, 2005)

One way to improve management in small businesses is external cooperation with a second, larger company, one that is also their business partner. In this case, there is a certain link between the output 
information of both partners, when the selected aggregated data is provided by the small business to the larger partner (meaning the manufacturer and the regional distributor.)

In this second business (with three-level management system), internal transactional data is summarized and evaluated by tactical management. Both internal and external data (in this case from multiple distribution companies) is used for the purposes of strategic management, which influences and complements the management in the small companies by feedback (such aschanges in pricing policy, recommendations, forecasts, etc.) (Fig.2). The arrows show the transfer of information within individual entities (labelled II) and the mutual exchange of information (labelled EI).

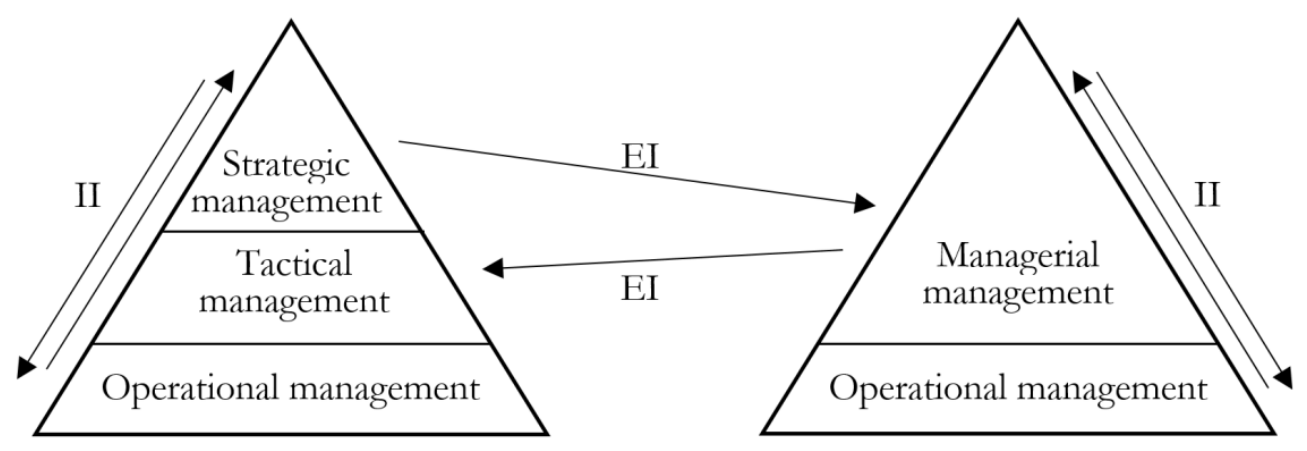

Figure 2. The collaboration of a small and large business

Source: (Myšková, 2005)

By co-operating with these entities, conditions are created externally in the small company thatreplaces the missing management level. The elements of the strategic management of a larger partner are reflected very quickly and effectively in the management of small or medium-sized companies.

In this way, additional information is provided to identify areas where changes can be made that may have a significant impact on the monitored business. At present, when competition is gaining a new, global character, such cooperation may bring a number of benefits.

\subsection{Aim and hypotheses}

Based on the above characteristics, the following hypotheses $(\mathrm{H})$ were established:

H1: In most SME's, only operational and tactical management is applied, strategic management is missing.

H2: Management of SME's do not share information with each other, but are aware of the lack of information from an external environment.

The aim of this article is to assess the interest of management of selected companies in sharing information and to specify which areas should be informally supported and shared from the point of view of these companies. The aim of this empirical research is also to confirm or rebut these hypotheses.

\subsection{Empirical research}

Empirical research was conducted through a questionnaire survey where managers or business owners in managerial positions were approached. The distribution network includes 25 commercial businesses that provide distribution of medical devices in the form of delivery to the end consumer under contract terms with the manufacturing company. These are 22 small businesses and 3 medium-sized businesses (according to criteria established within the European Union). They develop their 
entrepreneurial procedures as part of their business activity. Distributors have no exclusivity (in accordance with the laws in force in the Czech Republic).

The manufacturing company operates in the field of medical devices manufacturing.The company supplies its products to the distribution network (mentioned 25 commercial businesses).It is a transnational company that originated in the United States and gradually expanded its interests to Europe, where it gradually founded or acquired subsidiary companies. One of the subsidiary companies operates in the Czech Republic, supplying primarily the Czech Republic and Slovakia.

The research was conducted in two rounds. In April 2018, information on the levels of management ofselected companies, willingness to share information with other entities as well as specific areas from which information can be shared was obtained through a questionnaire survey, results are in the Table 1 . On the basis of these findings, a second questionnaire was created in September 2018, which already contained areas suitable for information sharing targeted according to the needs of the respondents. They commented on their importance and how frequentlywould they specifically use them. Due to personal connections, research was carried out where the population and the research data sample were the same respondents werethe responsible persons (managers) of individual enterprises. A matching questionnaire was given to the manufacturing company and the answers received are also evaluated in the next chapter (Table 2 and Table 3).

The relative frequencies allowed to evaluate the levels of management, the significance of the areas of information to be shared was determined using a five-point Likert scale and statistical characteristics of the location were used for the evaluation.

\section{EMPIRICAL RESULTS AND DISCUSSION}

The first part of the research revealed that managers of distribution companies were very critical in their assessment of strategic management; none expressed full satisfaction. However, the need for more information was felt differently - managements of two companies did not feel that acquiring more information about their environment was necessary, on the grounds that they already had sufficient data at their disposal. Only one of the respondents stated that they shared some information with another distributor. Somewhat surprising was the approach to information sharing in terms of the method used $20 \%$ of respondents were only willing to share information for a fee (see Table 1)

Table 1

Strategic management and the need to share external information

\begin{tabular}{|l|c|c|}
\hline & $\begin{array}{c}\text { Number of } \\
\text { respondents }\end{array}$ & Relative frequency (\%) \\
\hline $\begin{array}{l}\text { Managerial management (see Figure 1) - absence of strategic } \\
\text { management }\end{array}$ & 14 & 56 \\
\hline Insufficient strategic management & 11 & 44 \\
\hline The need to supplement external information & 23 & 4 \\
\hline $\begin{array}{l}\text { Partially sharing information with other distributors } \\
\text { (informal) }\end{array}$ & 1 & 76 \\
\hline $\begin{array}{l}\text { Willingness to share information within the distribution } \\
\text { network, of which }\end{array}$ & 3 & 12 \\
\hline Informally & 11 & 44 \\
\hline Formally - free of charge & 5 & 20 \\
\hline Formally - for a fee & 6 & 24 \\
\hline $\begin{array}{l}\text { Willingness to only share information with the } \\
\text { manufacturing company }\end{array}$ & 19 \\
\hline
\end{tabular}

Source: Authors' results 
Table 1 shows that the management of 14 businesses (more than $50 \%$ of respondents) consider their management as managerial (i.e. two-level), which confirms the H1 hypothesis. The need for other external information is felt by 23 companies, i.e. $92 \%$ of respondents. Hence, the $\mathrm{H} 2$ hypothesis may also be considered confirmed.

In the next part of the questionnaire survey, it was determined in which areas the managers feel the lack of information. Porter's Five Forces was used to facilitate responses and areas related to customers, suppliers, existing and potential competitors and substitutes were defined. In each of these areas, there was room for concretizing the requested information and more could be added depending on the respondents' choice. The acquired findings were summarized and in the second round of research given to the same respondents as well as the management of the manufacturing company.

Table 2

Areas of information interests and sources of information

\begin{tabular}{|c|c|c|c|c|c|}
\hline Area of interest & D-D & $\begin{array}{c}\text { Availa } \\
\text { ble } \\
\text { at D }\end{array}$ & D-MC & MC-D & $\begin{array}{c}\text { Availa } \\
\text { ble } \\
\text { at MC }\end{array}$ \\
\hline \multicolumn{6}{|l|}{ Customers } \\
\hline Customer structure & & $\mathrm{X}$ & & $\mathrm{X}$ & $\mathrm{X}$ \\
\hline Customers' requirements for the services provided & & $\mathrm{X}$ & & & \\
\hline Requirements for new forms of marketing (communication) & & $\mathrm{X}$ & & $\mathrm{X}$ & \\
\hline Requirements for supplementary product ranges & & $\mathrm{X}$ & & $\mathrm{X}$ & $\mathrm{X}$ \\
\hline Impact of legislation on customers (financing) & $\mathrm{X}$ & $\mathrm{X}$ & $\mathrm{X}$ & $\mathrm{X}$ & $\mathrm{X}$ \\
\hline The threat of losing a large customer & & $\mathrm{X}$ & & & $\mathrm{X}$ \\
\hline Product preferences & & $\mathrm{X}$ & & $\mathrm{X}(\mathrm{R})$ & $\mathrm{X}$ \\
\hline Quality perceived by customers & $\mathrm{X}$ & $\mathrm{X}$ & $\mathrm{X}$ & $\mathrm{X}(\mathrm{R})$ & $\mathrm{X}$ \\
\hline \multicolumn{6}{|l|}{ Suppliers } \\
\hline Changes in pricing policy & & & $\mathrm{X}$ & & $\mathrm{X}$ \\
\hline Changes in product and product range & $\mathrm{X}$ & & $\mathrm{X}$ & & $\mathrm{X}$ \\
\hline Research and development of new products & & & $\mathrm{X}$ & & $\mathrm{X}$ \\
\hline Direct deliveries outside the distribution network & $\mathrm{X}$ & & $\mathrm{X}$ & & $\mathrm{X}$ \\
\hline \multicolumn{6}{|l|}{ Existing competition (rivalry) } \\
\hline Number and size of competitors & $\mathrm{X}$ & $\mathrm{X}$ & $\mathrm{X}$ & $\mathrm{X}$ & $\mathrm{X}$ \\
\hline The geographical scope of competition & & & $\mathrm{X}$ & & $\mathrm{X}$ \\
\hline Changes in pricing policy & & $\mathrm{X}$ & & & $\mathrm{X}$ \\
\hline Scope and type of services provided & & $\mathrm{X}$ & & $\mathrm{X}$ & $\mathrm{X}$ \\
\hline Quality of competing products & $\mathrm{X}$ & $\mathrm{X}$ & & $\mathrm{X}$ & $\mathrm{X}$ \\
\hline \multicolumn{6}{|l|}{ Substitutes } \\
\hline New competing products & $\mathrm{X}$ & $\mathrm{X}$ & $\mathrm{X}$ & $\mathrm{X}$ & $\mathrm{X}$ \\
\hline Price policy of competition & & $\mathrm{X}$ & & $\mathrm{X}$ & $\mathrm{X}$ \\
\hline Development of new competing products & $\mathrm{X}$ & $\mathrm{X}$ & & & $\mathrm{X}$ \\
\hline Changes in technical parameters of competing products & & & $\mathrm{X}$ & & $\mathrm{X}$ \\
\hline \multicolumn{6}{|l|}{ The threat of new competition } \\
\hline Expandingthe existing distribution network & & & $\mathrm{X}$ & & $\mathrm{X}$ \\
\hline The entryof new competitors within another distro. network & & & $\mathrm{X}$ & & $\mathrm{X}$ \\
\hline The entry of international competitors & & & $\mathrm{X}$ & & $\mathrm{X}$ \\
\hline Access to raw materials, production know-how & & & $\mathrm{X}$ & & $\mathrm{X}$ \\
\hline
\end{tabular}

Legend: D-D: Distributor to Distributor, D-MC: Distributor to Manufacturing Company, MC-D: Manufacturing Company to Distributor, Regular Report to Manufacturing Company

Source: Authors' results

The results are shown in Tables 2 and 3. Table 2 specifies what information is available to the distributors and what to the manufacturing company, and at the same time, it summarizes what 
information the distributors are willing to share among themselves, what they would like to obtain from the manufacturing company and what information the manufacturing company requires from them.

Table 2 shows that some information is available to both distributors and manufacturing company, however, distributors possess specific information about their customers in particular. Their advantage is the detailed knowledge of customers, of their requirements for additional services and how to communicate with them. All respondents put special emphasis on the need to know the legislative environment, the upcoming changes in the area of public sector financing, as a large number of customers operate in the public sector, and the change in its funding is reflected in the demand for medical aids. The risk of losing a large customer is perceived as a significant factor, not only in the sense of choosing another manufacturer, but also another distributor within the distribution network. The research has clearly shown that distributors consider each other as competitors rather than cooperating entities.

As for assessing suppliers, the situation is specific as there is only one supplier being assessed (although some of the distributors also sell products of other manufacturers). The requests for information were therefore directed to the manufacturing company, although some concerns about their exclusivity also emerged from the responses, and were reflected in the unwillingness to informally share even the smallest indications of changes of products or product ranges. The possibility of delivering products directly outside the distribution network clearly gives rise to concern as well.

The interest in information about competitors is high, as distributors know their market segment and the manufacturing company has more information about competing manufacturing companies. Similarly, the quality of existing competing products and their price, as well as the possibilities of newly developed products, are being closely monitored. In terms of the threat of new competition, distributors are cautious about expanding the distribution network and the entry of new competitors, including foreign ones.

Table 3 provides an assessment of the importance of the required information from the point of view of both the distributors and the manufacturing company. The scale ranged from 1-5, with 5 meaning that the respondent strongly agrees that the required information is important. Location characteristics were used, which reveal the scattering of the answers obtained. The manager responsible was in charge of answering for the manufacturing company, and therefore only one value corresponding to the used scale is given.

Table 3

The importance of information in the selected areas from the point of view of distributors (SMES's) and the manufacturing company

\begin{tabular}{|c|c|c|c|c|c|}
\hline \multirow[b]{2}{*}{ Area of interest } & \multicolumn{4}{|c|}{$\begin{array}{c}\text { Distributors } \\
\text { (SME's) }\end{array}$} & \multirow[t]{2}{*}{$\begin{array}{c}\text { Manufacturing } \\
\text { Company }\end{array}$} \\
\hline & Median & Modus & Average & Deviation & \\
\hline \multicolumn{6}{|l|}{ Customers } \\
\hline Customer structure & 3.5 & 4 & 3.40909 & 0.79636 & 4 \\
\hline Customers' requirements for the services provided & 4 & 4 & 3.86363 & 0.88884 & * \\
\hline Requirements for new forms of communication & 3 & 3 & 3.45454 & 0.80043 & 2 \\
\hline Requirements for supplementary product ranges & 4 & 4 & 4.09090 & 0.68376 & 4 \\
\hline Impact of legislation on customers (financing) & 4.5 & 5 & 4.31818 & 0.77988 & 2 \\
\hline The threat of losing a large customer & 5 & 5 & 4.36363 & 0.78954 & * \\
\hline Product preferences & 4.5 & 5 & 4.31818 & 0.77988 & 5 \\
\hline Quality perceived by customers & 4 & 4 & 4 & 0.69006 & 5 \\
\hline \multicolumn{6}{|l|}{ Suppliers } \\
\hline Changes in pricing policy & 3 & 2 & 2.63636 & 1.00216 & * \\
\hline Changes in products and product range & 3 & 3 & 2.59090 & 0.73414 & * \\
\hline Research and development of new products & 3 & 3 & 2.63636 & 0.78954 & * \\
\hline Direct deliveries outside the distribution network & 4.5 & 5 & 4.31818 & 0.77988 & * \\
\hline
\end{tabular}




\begin{tabular}{|l|c|c|c|c|c|}
\hline Existing competition (rivalry) & & & & & \\
\hline Number and size of competitors & 4 & 4 & 4.13636 & 0.77431 & 5 \\
\hline Geographical scope of competition & 4 & 4 & 4.09090 & 0.68376 & $*$ \\
\hline Changes in pricing policy & 4 & 4 & 4 & 0.69006 & $*$ \\
\hline Scope and type of services provided & 4.5 & 5 & 4.31818 & 0.77988 & 3 \\
\hline Quality of competing products & 4 & 4 & 4.18181 & 0.58849 & 5 \\
\hline Substitutes & & & & & \\
\hline New competing products & 4.5 & 5 & 4.31818 & 0.77988 & 5 \\
\hline Price policy of competition & 4 & 5 & 4.36363 & 0.65795 & 5 \\
\hline Development of new competing products & 2.5 & 2 & 2.59090 & 0.79636 & $*$ \\
\hline Changes in tech. parameters of competing products & 3 & 3 & 3.04545 & 0.65299 & $*$ \\
\hline The threat of new competition & & & & & \\
\hline Expanding existing distribution network & 4 & 4 & 4.22727 & 0.68534 & $*$ \\
\hline $\begin{array}{l}\text { The entry of new competitors within another distribution } \\
\text { network }\end{array}$ & 3 & 3 & 2.90909 & 0.68376 & $*$ \\
\hline Entry of international competition & 2 & 2 & 2.04545 & 0.72225 & $*$ \\
\hline Access to raw materials, production know-how & 2.5 & 2 & 2.5 & 0.67259 & $*$ \\
\hline
\end{tabular}

* The manufacturing company is not interested in following the areas.

Source: Authors' results

Table 3 shows that distributors are most interested in information about customers and the current competition. The number of sub-areas where distributors would welcome greater awareness corresponds to how they assessed the significance of the five basic modules defined by the Five-Force model. The criterion for determining this significance is the percentage of importance based on the median in Table 3 for the importance of individual requirements. Taking into account the maximum significance of the criterion corresponding to the value of 5 , then the quotient of the sum of the medians obtained and the maximum possible values for the given area corresponds to the significance of the observed area (Table 4).

Table 4

Importance of monitored information areas from a distributor's perspective

\begin{tabular}{|l|c|c|c|}
\hline \multicolumn{1}{|c|}{ Area of interest } & $\begin{array}{c}\text { Number of sub-areas } \\
\text { of interest }\end{array}$ & $\begin{array}{c}\text { Importance of area } \\
\text { (in \%) }\end{array}$ & $\begin{array}{c}\text { Importance of area } \\
\text { (standardized) }\end{array}$ \\
\hline Customers & 8 & $32.5 / 40=81$ & 0.23 \\
\hline Suppliers & 4 & $13.5 / 20=67.5$ & 0.19 \\
\hline Existing competition (rivalry) & 5 & $20.5 / 25=82$ & 0.23 \\
\hline Substitutes & 4 & $14 / 20=70$ & 0.20 \\
\hline The threat of new competition & 4 & $11.5 / 20=57.5$ & 0.16 \\
\hline
\end{tabular}

Source: Authors' results

The manufacturing company, on the other hand, seems to be interested mainly in acquiring more data about competitors' products (quality and price), the structure of the existing customers of individual distributors and their requirements for new product ranges. What may be held against them is the general lack of interest in what services customers require, and how requirements for communication between vendors and customers change.

The research has provided interesting insights, but it is also necessary to mention its limitations. Firstly, the product type is quite specific and designed for specific customers, which is manifested in the methods of ordering (often on the basis of a selection process) and in customer loyalty acquired through long-term cooperation and provision of additional services (advice, maintenance service). The distribution 
network is also relatively unchanged; the number of distributors has not been increasing. Distributors consider each other competitors rather than cooperating entities, so the willingness to share information is limited by fear of possible misuse of the information provided to their detriment. This is similarly reflected in what information the distributors are willing to share with the manufacturer and among each other. As far as the assessed areas and the information required are concerned, it is not always clear whether the information is strategically oriented. This is because respondents are not always economists and do not know the economic theory. However, research with the data acquired from the respondents from all companies in the distribution network provided insights that did not need to be generalized as the sample was equal to the base population.

We hypothesized that "in most small businesses, only operational and tactical management is applied, strategic management is missing". (H1). This hypothesis has been confirmed. The second hypothesis (H2) stated that "management of small businesses do not share information with each other, but are aware of the lack of information from an external environment ". This hypothesis has also been confirmed.

\section{CONCLUSION}

Information about external environment influences is crucial for the further development of each business entity, however, the acquisition and evaluation of this information in SMEs is not sufficient for long-term business strategy. This is also due to the difference in management - in the practice of small businesses, tactical management is still preferred and the need for three-level management is underestimated. Considering that even small businesses need external information for long-term, strategic decision-making, there is a room for cooperation between these entities, which may have the character of contractual co-operation.

The research showed that the respondents considered important information concerning customers and existing competitors and their products. Specifically, this is about sharing information in impact of legislation on customers (financing), quality perceived by customers, number and size of competitors, quality of competing products, direct deliveries outside the distribution network, new competing products. These data were of great importance to respondents.They are willing to share even more information. It can be assumed that the findings are also useful in other, similar business networks operating in other sectors, which should be the subject of further research.

In this paper, we aimed to explore to what extent management of individual enterprises are interested in information sharing and finding and specifying areas that are suitable for information support and sharing.

The conducted research has shown that small businesses lack the strategic level of management, and management focuses primarily on obtaining information about their surroundings in connection with operational management. Even within the distribution network, the willingness to share information is limited by the fear of its misuse by another entity. Information sharing is, therefore, more feasible between the distributor and the manufacturing company.

The methodology outlined in this article is useful in analysis what external information SMEs are missing and whether this can be obtained by sharing information with other businesses. Identifying these deficiencies is necessary to build a future communication platform.

\section{ACKNOWLEDGEMENT}

The authors are thankful to the Grantová agentura Akademické alliance No. 8/2018: "Support managerial decision making in SMEs by sharing of strategically important information" for financial support to carry out this research. 


\section{REFERENCES}

Achterberg, H.L., Omar, M., Ambituuni, A., \&Roll, O. (2018). Facts or gut feelings: analysis of external pricing antecedents for SMEs in Germany. Journal of Small Business and Enterprise Development, 25(6), 886-901. http://dx.doi.org/10.1108/JSBED-12-2017-0398

Bednářová, D. (2008). Charakteristika a činnost klastrů v Jihočeském kraji. E+M Ekonomie a Management, 11(4), 84-92.

Belás, J., Bartoš, P., Habánik, J., \& Novák, P. (2014). Significant Attributes of the Business Environment in Small and Meduim-Sized Enterprises. Economics and Sociology, 7(3), 22-39. http://dx.doi.org/10.14254/2071789X.2014/7-3/2

Belás, J., Vojtovič, S., Ključnikov, A. (2016). Microenterprises and Significant Risk Factors in Loan Process. Economics and Sociology, 9(1), pp. 43-59. http://dx.doi.org/10.14254/2071-789X.2016/9-1/3

Bengtsson, M. \& Kock, S. (1999). Cooperation and competition in relationships between competitors in business networks. Journal of Business \& Industrial Marketing, 14(3), 178-194. https://doi.org/10.1108/08858629910272184

Bengtsson, M., Eriksson, J. \& Wincent, J. (2010). Co-opetition dynamics - an outline for further inquiry. Competitiveness Review: An International Business Journal incorporating Journal of Global Competitiveness, 20(2), $194-214$. https://doi.org/10.1108/10595421011029893

Brien, E.O., \& Hamburg, I. (2014). Supporting Sustainable Strategies for SMEs through Training, Cooperation and Mentoring. Higher Education Studies, 4(2), 61-69. http://dx.doi.org/10.5539/hes.v4n2p61

Cepel, M., Stasiukynas, A., Kotaskova, A., \& Dvorsky, J. (2018). Business Environment Quality Index in the SME Segment. Journal of Competitiveness, Vol. 10, Issue 1, pp. 21-40. DOI: 10.7441/joc.2018.02.02

Chander, V. (2018). Coopetition and Business Models. Working paper. Cambridge, Cambridge Service Alliance. https://cambridgeservicealliance.eng.cam.ac.uk/resources/Downloads/Monthly\%20Papers/July2018Paper.p df

Dahl, J. (2014). Conceptualizing coopetition as a process: An outline of change in cooperative and competitive interactions. Industrial Marketing Management, 43(2), 272-279. https://doi.org/10.1016/j.indmarman.2013.12.

Desouza, K.C., \& Awazu, Y. (2006). Knowledge management at SMEs: five peculiarities. Journal of Knowledge Management, 10(1), 32-43. http://dx.doi.org/10.1108/13673270610650085.

Dixit, A., \& Pandey, A.K. (2011). SMEs and economic growth in India: cointegration analysis. IUP Journal of Financial Economics, 9(2), 41-59.

Fernandez, A.S., Le Roy, F. \& Gnyawali, D.R. (2014). Sources and management of tension in co-opetition case evidence from telecommunications satellites manufacturing in Europe. Industrial Marketing Management, 43(2), 222-235.

Galdeano-Gómez, E., Perez-Mesa, J. C., \& Aznar-Sánchez, J. A. (2016). Internationalisation of SMEs and simultaneous strategies of cooperation and competition: an exploratory analysis. Journal of Business Economics and Management, 17(6), 1114-1132. http:/ /dx.doi.org/10.3846/16111699.2014.959040

Horgan, D., van Kranen, H. J., \& Morré, S. A. (2018). Optimising SME Potential in Modern Healthcare Systems: Challenges, Opportunities and Policy Recommendations. Public Health Genomics, 21, 1-17. http://dx.doi.org/10.1159/000492809

Howlett, R.J., Gabrys, B., Musial-Gabrys, K. \& Roach, J. (2013). Innovation through Knowledge Transfer 2012. Bournemouth, Springer Science \& Business Media.

Hudakova, M., Masar, M., Luskova, M., \& Patak, M.R. (2018). The Dependence of Perceived Business Risks on the Size of SMEs. Journal of Competitiveness, 10(4), 54-69. http://dx.doi.org/10.7441/joc.2018.04.04

Kaufmann, H.R., Tsangar, H., \& Vrontis, D. (2012). Innovativeness of European SMEs: Mission not yet accomplished, Economic Research-Ekonomska Istraživanja, 25(2), 333-359. http://dx.doi.org/10.1080/1331677X.2012.11517511

Kirschenbaum, K., \& Norden, L. (2012). The Relationship between Borrower Risk and Loan Maturity in Small Business Lending, Journal of Business Finance \& Accounting, 39(5-6), 730-757. http://dx.doi.org/10.1111/j.14685957.2012.02285.x 
Kljucnikov, A., Sobekova-Majkova, M., Vincurova, Z., Sarvutyte-Gailiuniene, M., \& Kiausiene, I. (2018). The Insolvency of SMEs within the Perspective of the Central European Region. Transformations in Business \& Economics, 17(2), 210-24.

Ključnikov, A., Belás, J., Kozubíková, L., \& Paseková, P. (2016). The Entreprenurial Perception of SME Business Environment Quality in the Czech Republic. Journal of Competitiveness, Vol. 8, Issue 1, pp. 66-78. DOI: 10.7441/joc.2016.01.05

Kumar, R., Singh, R. \& Shankar, R. (2016). Study on collaboration and information sharing practices for SCM in Indian SME. International Journal of Business Information Systems, 22(4), 455-475. http://10.1504/IJBIS.2016.077838

Lawson, B., Petersen, K.J., Cousins, P.D., \& Handfield, R.B. (2009) Knowledge Sharing in Interorganizational Product Development Teams: The Effect of Formal and Informal Socialization Mechanisms. Journal of Product Innovation Management 26, 156-172.https://doi.org/10.1111/j.1540-5885.2009.00343

Levy, M., Loebbecke, C., \& Powell, P. (2003). SMEs, co-opetition and knowledge sharing: the role of information systems. European Journal of Information Systems, 12(1), 3-17. http://dx.doi.org/10.1057/palgrave.ejis.3000439

Mei, S., \& Nie, M. (2007). Relationship between Knowledge Sharing, Knowledge Characteristics, Absorptive capacity and Innovation: an empirical study of Wuhan Optoelectronic Cluster. The Business Review, 7(2), 154-161.

Meixnerová, L., Menšík, M., \& Pászto, V. (2017). Economic analysis and spatial arrangements of engineering SMEs performance in Olomouc region of Czech Republic. Journal of International Studies, 10(1), 135-145. http:/ /dx.doi.org/10.14254/2071-8330.2017/10-1/9

MIT Ministry of Industry and Trade (2017). Zpráva o MSP. https://www.mpo.cz/assets/cz/podnikani/male-astredni-podnikani/studie-a-strategicke-dokumenty/2018/10/Zprava_SMES_2017.pdf

Muscio, A. (2007). The Impact of Absortive Capacity on SMEs' Collaboration. Economics of Innovation and New Technology, 16(8), 653-668. doi: http://dx.doi.org/10.1080/10438590600983994

Myšková, R. (2005). Př́nosy vyplývající ze spolupráce malých a středních podniků v rámci regionu. Regionálny rozvoj 2005. Žilina: Žilinská univerzita, 79-84. ISBN 80-8070-483-X.

Neuberger, D., \& Räthke, S. (2009), Microenterprises and multiple bank relationships: The case of professionals. Small Business Economics, 32(2), 207-229. http://dx.doi.org/10.1007/s11187-007-9076-8

Pan, Y.Q., Pavur, R., \& Pohlen, T. (2016). Revisiting the Effects of Forecasting Method Selection and Information Sharing Under Volatile Demand in SCM Applications. IEEE Transactions on Engineering Management. 63(4), 377-389, http://dx.doi.org/10.1109/TEM.2016.2580569

Pavelková, D., \& Jirčíková, E. (2008). Klastry jako nástroj zvýšení konkurenceschopnostifirem. E+M Ekonomie a Management, 11(3), 62-72.

Pooe, D., Mafini, C. \& LouryOkoumba, V.W. (2015). 'The influence of information sharing, supplier trust and supplier synergy on supplier performance: The case of small and medium enterprises. Journal of Transport and Supply Chain Management, 9(1), 187-188. doi: http://dx.doi. org/10.4102/jtscm.v9i1.187

Poufinas, T., Galanos, G., \& Papadimitriou, P. (2018). The Competitiveness of Small and Medium Enterprises in Adverse Economic Environments. Theoretical Economics Letters, 8, 2788-2802. http:/ /dx.doi.org/10.4236/tel.2018.813175

Ritala, P. \& Tidström, A. (2014). Untangling the value-creation and value-appropriation elements of coopetition strategy: A longitudinal analysis on the firm and relational levels. Scandinavian Journal of Management, 30(4), 498515. http://dx.doi.org/10.1016/j.scaman.2014.05.002

Ryad, T., Shadi. S., Yacine, R. (2016). Integration breach: Investigating the effect of internal and external information sharing and coordination on firm profit. International Journal of Production Economics, 181, Part A, 34-47, https://doi.org/10.1016/ j.ijpe.2016.01.002

Škarpová L., \& Grosová S. (2015). The Application of Business Network Approach for Small and Medium Enterprises (SME) with regard to their Buying Behavior. Journal of Competitiveness, 7(3), 62-74. http://dx.doi.org/10.7441/joc.2015.03.05

Sohn, S. Y., \& Lim, M. (2008). The effect of forecasting and information sharing in SCM for multi-generation products. European Journal of Operational Research, 186(1), 276-287. http://dx.doi.org/10.1016/j.ejor.2007.01.034 
Tidström, A. \& Hagberg-Andersson, A. (2012). Critical events in time and space when cooperation turns into competition in business relationships. Industrial Marketing Management, 41(2), 333-343. http://dx.doi.org/10.1016/j.indmarman.2012.01.005. 2011

Tidström, A., 2014. Managing tensions in coopetition. Industrial Marketing Management, 43(2), pp.261-271. Available at: http://dx.doi.org/10.1016/j.indmarman.2013.12.001.

Virglerová, Z., Kozubíková, L., \& Vojtovič, S. (2016). Influence of selected factors on financial risk management in SMEs in the Czech Republic. Montenegrin Journal of Economics, 12(1), 21-36. doi: http://dx.doi.org/10.14254/1800-5845.2016/12-1/1

Wijk, R., Jansen, J.J.P., Lyles, M. (2008). Inter- and Intra-Organizational Knowledge Transfer: A Meta-Analytic Review and Assessment of its Antecedents and Consequences. Journal of Management Studies 45(4).https://doi.org/10.1111/j.1467-6486.2008.00771

Zeng, S.X., Xie, X.M., \& Tam, C.M. (2010). Relationship between cooperation networks and innovation performance of SMEs. Technovation, 30(3), 181-194. http://dx.doi.org/10.1016/j.technovation.2009.08.003

Zhang, Q., Vonderembse, M.A., Lim, J.S. (2006). Spanning flexibility: supply chain information dissemination drives strategy development and customer satisfaction. Supply Chain Management: An International Journal, 11(5), 390399.https://doi.org/10.1108/13598540610682408 